\title{
Evaluation Of Analgesic And Anti Inflammatory Activity Of Siddha Drug Karuvilanchi Ver Chooranam (Root Powder Of Smilax Zeylanica Linn) In Rodents
}

\author{
Nithyamala I*, Ayyasamy S, Pitchiahkumar M, Kumar A, Velpandian V \\ Post Graduate Department of Gunapadam (Pharmacology), Government Siddha Medical College, \\ Arumbakkam, Chennai - 600 106, Tamilnadu, India.
}

\begin{abstract}
The present study was carried out to validate the anti-inflammatory and analgesic activities of Karuvilanchi ver chooranam (KVC) (Root powder of Smilax zeylanica) in rodents. Analgesic study was carried out by using Eddy's Hotplate method and acetic acid-induced writhing test and Anti inflammatory study was evaluated by Cotton pellet granuloma method and by plethysmometer method. The result of the analgesic activity evaluated using hot plate method revealed that the reaction time for mice was significantly increased in a dose dependent manner after one hour of oral administration. It was found that both KVC and Aspirin caused an inhibition on the writhing response induced by acetic acid. Doses of 250 and $500 \mathrm{mg} / \mathrm{kg}$ of the KVC and aspirin respectively, could completely block the writhing response exhibited about 61.51 and $72.51 \%$ inhibition. In acute inflammation model, the formalin induced paw oedema was significantly reduced by all the doses of $K V C$ used when compared to control $(P<0.05)$. The results of cotton pellet granuloma method indicated that $K V C$ in both doses significantly reduced the weight of the cotton pellet granuloma with a dose dependent effect. From the result it can be concluded that the trial drug Karuvilanchi Ver Chooranam has potent analgesic and anti inflammatory properties which confirmed the traditional use.
\end{abstract}

Key Words: Analgesic, Anti inflammatory, Karuvilanchi ver chooranam, Siddha drug , Smilax zeylanica

\section{Introduction}

Drugs which are used currently for pain management $\&$ inflammatory conditions are either narcotic analgesics or NSAID'S and steroids. All the above said drugs possess adverse $\&$ toxic effects such as addiction, constipation and respiratory depression in case of narcotic analgesics peptic ulcers and kidney problems in NSAID'S. So to avoid adverse effects from these medicines, potent and safe medicine from plant origin has been used since long time. It is essential that efforts should be made to introduce new medicinal plants to develop cheaper drugs ${ }^{[1]}$. Plants represent still a large untapped source of structurally novel compounds that might serve as a beacon light for the development of novel drugs ${ }^{[2]}$.

Analgesics and anti inflammatory drugs go hand in hand for most of the pain management nowadays. Inflammation has become the spotlight of global scientific research due to its severe implication \& sufferings in human beings. The search for conventional drugs to ameliorate the above said phenomenon which are non toxic, cheaper easily available has lead to the development of new drug from the traditional resources. One of the analgesic and anti inflammatory drug is Karuvilanchi ver (root of Smilax zeylanica) which is one of the main constituent of many preparations in Siddha system of medicine used in the treatment of pain management and prevents the inflammatory process. The Siddha classical literature, 'Vadha Noi Nidhanam 800' mentioned the above said properties. ${ }^{[3]}$.

Karuvilanchi (Smilax zeylanica) is a climber with slender 4 - angular branches found throughout the tropical hilly areas from the Himalayas southward to Kerala ${ }^{[4]}$. Even though it is used in the treatment of pain and inflammatory management for a long time in Siddha system of medicine, the plant has not been scientifically validated for its anti inflammatory and analgesic activity. So the aim of the present study was to evaluate the safety, analgesic and anti inflammatory activity of Karuvilanchi ver chooranam (root powder of Smilax zeylanica) in animal models.

\subsection{Preparation of Karuvilanchi Ver Chooranam (KVC)}

\section{Materials And Methods}

The plant material Smilax zeylanica used in this study was collected from Kanyakumari Dist, Tamilnadu. After collection, the plant was identified and authenticated by the Gunapadam experts in, Govt. siddha medical college, Chennai-106 and by Botanist, Central Research Institute for Siddha, Arumbakkam, Chennai-106. The voucher specimen was preserved in the department for future reference. After identification, the roots of plant were separated and rinsed well in water to remove the impurities. Then the roots were cut into pieces and dried in shade. The well dried roots of Smilax zeylanica (Karuvilanchi ver) were made into fine 
powder sieved through a white cotton cloth (Vashthirakayam) and the chooranam (KVC) was obtained. The Chooranam was then purified according to the procedure in the Siddha literature 'Chikitcha Rathna Deepam,

\subsection{Drugs and chemicals}

Chemicals used in the present study such as Formalin, acetic acid and CMC were obtained from Sigma-Aldrich Chemicals. Chemicals used in the present study such as Formalin, acetic acid and CMC were obtained from Sigma-Aldrich Chemicals. All the chemicals and drugs used in the study were of analytical grade.

\subsection{Preparation of stock solution}

$K V C$ suspended with $2 \%$ carboxy methyl cellulose and the stock solution was prepared. The stock solution concentration was $200 \mathrm{mg} / \mathrm{ml}$.

\subsection{Animals}

Albino mice (22-28 g) and Wistar rats (180-200 g) either sex were obtained from the animal house of department of pharmacology, Vels University, Chennai. All Animals were well maintained at standard laboratory conditions and fed with standard feeding pellets (Sai durga foods, Bangalore) and water ad libitum. Prior to treatment, the animals were fasted for $10 \mathrm{~h}$ for mice and $12 \mathrm{~h}$ for rats respectively. However, water was made available ad libitum. This study was approved by the institutional animal ethical committee (IAEC) with approval number: XIII/VELS/PCOL/16/2000/CPCSEA/IAEC/08.08.2012).

\subsection{Acute toxicity}

Acute oral toxicity test for the Karuvilanchi ver chooranam was carried out as per OECD Guidelines $425^{[6,7]}$. The test substance was administered in a single dose by gavage using a stomach tube. The dose of the test substance was determined by the fasted body weight of each animal and the correct dose was calculated. After the trial drug has been administered, food was withheld for a further 2 hours in mice. The animals were observed continuously for the first $4 \mathrm{~h}$ and then each hour for the next $24 \mathrm{~h}$ and at 6 hourly intervals for the following $48 \mathrm{~h}$ after administering the test drug, to observe any death or changes in general behaviour and other physiological activities. The time of onset, intensity, and duration of these signs, if any, was recorded.

\subsection{Evaluation of analgesic activity by Eddy's Hotplate method}

The hot-plate test method was employed to assess the analgesic activity ${ }^{[8,9]}$. The temperature of the cylinder was set at $55 \pm 0.5^{\circ} \mathrm{C}$. The experimental mice were divided into four groups. Each mouse acted as its own control. Before administration of test drugs, the reaction time of each mouse (licking of the forepaws or jumping response) was noted at 0 and $10 \mathrm{~min}$ interval. The average of the two readings was obtained as the initial reaction time. The reaction time following the administration of the $K V C(250,500 \mathrm{mg} / \mathrm{kg}$, p.o.), Pentazocine (5mg/kg) and Saline (p.o.), was measured at 30,60and 120 minutes after a latency period of 30 $\mathrm{min}$. From the measurement, the percentage of analgesic activity was calculated and recorded.

\subsection{Antinociceptive testing}

The antinociceptive property of $K V C$ was tested using the model of writhing response in mice ${ }^{[10,11,12]}$. Swiss albino mice of either sexes weighing 20-30 g were used. The writhing syndrome was brought out by the administration of $0.7 \%$ acetic acid at the dose of $0.1 \mathrm{ml} / 10 \mathrm{~g}$ body weight intra peritoneally. Test substances and control vehicle were orally administered into the mice $30 \mathrm{~min}$ before the injection of acetic acid and the number of writhes was noted for $25 \mathrm{~min}$ at the beginning and $5 \mathrm{~min}$ after acetic acid injection.

\subsection{Evaluation of acute anti-inflammatory activity by plethysmometer method}

Acute anti inflammatory activity of Karuvilanchi ver chooranam was evaluated by plethysmometer method ${ }^{[13]}$. The animals were divided into four groups. First group considered as vehicle control which was treated with saline $(3 \mathrm{ml} / \mathrm{kg})$ only. Fourth group termed as standard group which was administered by the reference drug acetyl salicylic acid $(100 \mathrm{mg} / \mathrm{kg})$. The second and third groups considered as test groups and were treated with $K V C 250$ and $K V C 500$ respectively. All the drugs were administered orally. The drugs were administered simultaneously with formalin injection. Acute inflammation was elicited by subplantar injection of $0.1 \mathrm{ml}$ of $1 \%$ suspension of formalin in normal saline in the right hind paw of the rats. Paw volume was measured plethysmometrically at ' 0 ' -'2' hours after formalin injection. Mean increase in paw volume was measured and Percentage of inhibition of test drugs was statistically calculated and compared with vehicle control and standard drug. 


\subsection{Cotton pellet granuloma pouch method}

Chronic inflammation was induced by cotton pellet granuloma method ${ }^{[14]}$. Rats were divided into four groups. First two groups received oral doses of 250 and $500 \mathrm{mg} / \mathrm{kg}$ of $K V C$ respectively. The reference drug indomethacin $(10 \mathrm{mg} / \mathrm{kg})$ was used as a positive control and the other negative control group received saline solution. Sterilized Cotton pellets $50 \mathrm{mg}$ were implanted under light ether anesthesia in the axilla and groin region of each rat by making a small incision Drugs (KVC 250, KVC 500 and Indomethacin) and saline ( $5 \mathrm{ml} / \mathrm{kg}$ ) for control group were administered orally to four groups of rats once daily for 7 consecutive days from the day of cotton pellet implantation. The $8^{\text {th }}$ day, the animals were sacrificed and cotton pellets were removed and dried in an oven at $60^{\circ} \mathrm{C}$ for 24 hours. They were then weighed. The granuloma formation was calculated as a measure of increment in the dry weight of the pellet. The percentage of inhibition of granuloma was calculated using the following formula.

$$
\mathrm{P}=(1-\mathrm{Wt} / \mathrm{Wc}) \times 100,
$$

where, Wt - Dry weight of the cotton in test animals and Wc - Dry weight of the cotton in control animals.

\section{Statistical data}

Data were presented as mean \pm S.E.M. Statistical differences between control and treated groups were tested by one way ANOVA followed by dunnet's test.

\subsection{Acute toxicity studies}

\section{Results}

Using acute toxicity study in mice the non-toxic effect of $K V C$ in mice was confirmed and the safety of the drug was ensured up to $5 \mathrm{~g} / \mathrm{kg}$ upon oral administration. Hence the therapeutic dose was finalized as 250 and $500 \mathrm{mg} / \mathrm{kg}$.

\subsection{Eddy's Hotplate method}

The results of the effect of $K V C$ on pain induced by hot plate method are given in Table 1. As pentazocine, KVC 250 and $K V C 500$ significantly increased percentage of reaction time with dose dependent response.

\subsection{Antinociceptive testing}

The results of the effect of $K V C$ on writhing response in mice are given in Table 2 and Fig.1. KVC 250 and $K V C 500$ significantly reduced the number of abdominal cramps induced by acetic acid when compared to the negative control group. This inhibition was also dose dependent.

\subsection{Acute anti-inflammatory activity}

The results of the effect of $K V C$ on formalin-induced edema in hind Paw of rats is given in Table 3 and Fig.2. The edema volume increased over time, this increase was greater in the group treated by the saline and lesser in KVC 250, KVC 500 and acetyl salycilic acid. These results were significant compared to the control group ( $\mathrm{P}<0.05$ and $\mathrm{P}<0.01$ ). The percentage of inhibition was $11.90 \%$ and $16.66 \%$ for $K V C 250$ and $K V C$ 500 respectively. In the same condition acetyl salicylic acid $100 \mathrm{mg} / \mathrm{kg}$ has a percentage of inhibition of 33.33.

\subsection{Cotton pellet granuloma pouch method}

The percentage of inhibition of granuloma in Cotton pellet granuloma pouch method is shown in Table 4 and Fig.3. From this result it was observed that both doses of Karuvilanchi ver chooranam (KVC 250 and $K V C 500)$ significantly inhibited granuloma weight $(\mathrm{P}<0.05$ and $\mathrm{P}<0.01$ respectively) when compared to the control group. The percentage of inhibition of $K V C 250$ and $K V C 500$ were $69.60 \%$ and $76.17 \%$ respectively which indicated the dose dependent activity of Karuvilanchi ver chooranam. KVC 500 exhibited percentage of inhibition more than $K V C 250$ and slightly less than the reference drug Indomethacin $(100 \mathrm{mg} / \mathrm{kg})$ which produced $91.19 \%$ of inhibition. 
Table 1: Effect of $K V C$ on pain induced by hot plate method

\begin{tabular}{|c|c|c|c|c|c|}
\hline Treatment & Dose & \multirow{2}{*}{$\begin{array}{c}\text { Reaction time in } \\
\text { sec. before drug }\end{array}$} & \multicolumn{3}{|c|}{ \% increase in reaction time after drug } \\
& & & 30min & 60min & 120min \\
\cline { 3 - 6 } & & $2.8 \pm 0.05$ & $12.4 \pm 0.04$ & $13.2 \pm 0.4$ & $14.10 \pm 0.5$ \\
\hline Saline & $3 \mathrm{ml} / \mathrm{kg}$ & $3.0 \pm 0.04$ & $22.2 \pm 0.36^{* *}$ & $28.23 \pm 1.12^{* *}$ & $32.24 \pm 2.11^{* *}$ \\
\hline$K V C$ & $250 \mathrm{mg} / \mathrm{kg}$ & $2.8 \pm 0.05$ & $36.1 \pm 0.40^{* *}$ & $44.29 \pm 1.20^{* *}$ & $47.02 \pm 2.24^{* *}$ \\
\hline$K V C$ & $500 \mathrm{mg} / \mathrm{kg}$ & $3.1 \pm 0.14^{*}$ & $66.22 \pm 1.28^{* *}$ & $68.17 \pm 2.00^{* *}$ & $67.34 \pm 1.82^{* *}$ \\
\hline Pentazocine & $5 \mathrm{mg} / \mathrm{kg}$ & &
\end{tabular}

Values expressed in mean \pm SEM and units in seconds, Significant $* p<0.05, * * P<0.01 \quad(n=6)$

Table 2: Effect of $K V C$ on writhing response in mice

\begin{tabular}{|c|c|c|}
\hline Experiment & Number of writhes & Inhibition (\%) \\
\hline Control & $38.2 \pm 7.3$ & ---- \\
\hline$K V C 250 \mathrm{mg} / \mathrm{kg}$ & $14.7 \pm 5.0^{*}$ & 61.51 \\
\hline$K V C 500 \mathrm{mg} / \mathrm{kg}$ & $10.5 \pm 4.8^{* *}$ & 72.51 \\
\hline Aspirin $150 \mathrm{mg} / \mathrm{kg}$ & $6.3 \pm 2.4^{* *}$ & 83.50 \\
\hline
\end{tabular}

Values are expressed as Mean \pm S.E.M. $* P<0.05$; significantly different from the control group $(N=6)$.

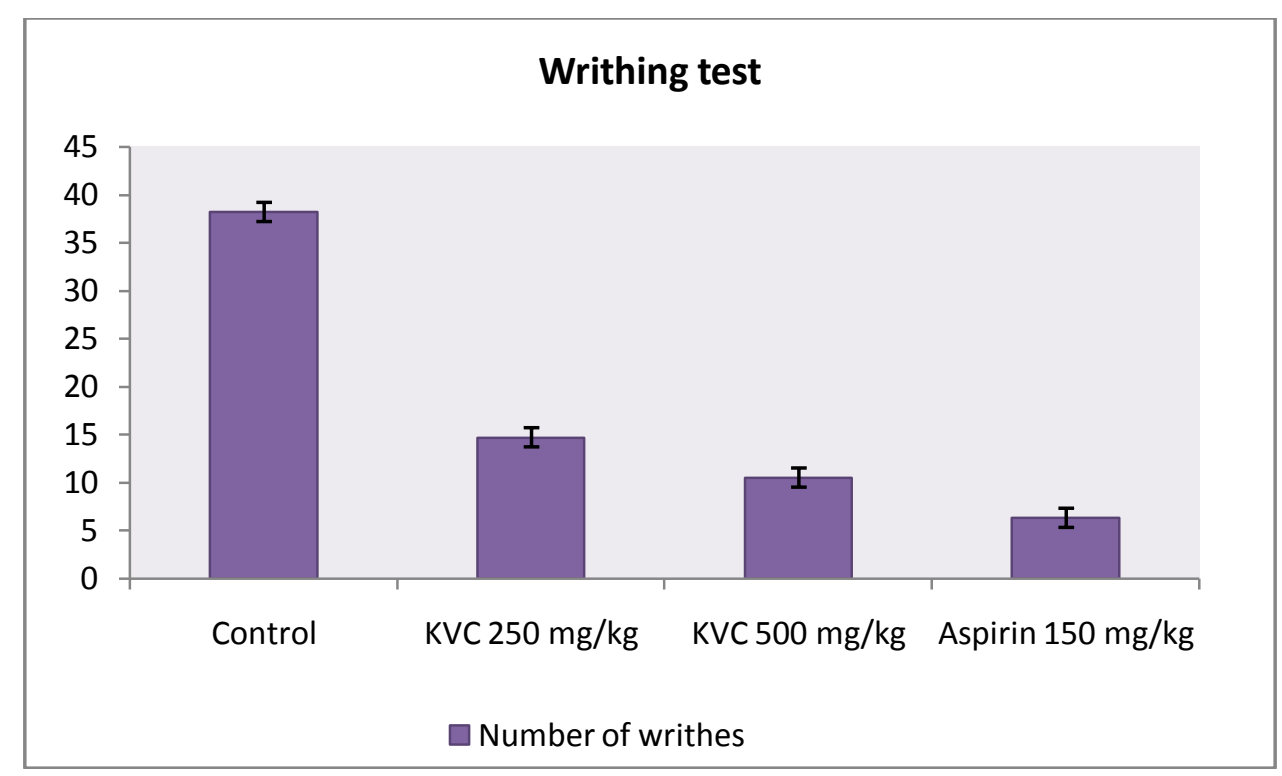

Fig -1 Effect of $K V C$ on writhing response in mice

Table 3. Effect of $K V C$ on formalin-induced edema in hind Paw of rats

\begin{tabular}{|l|l|c|c|c|}
\hline S.No & \multicolumn{1}{|c|}{ Treatment } & Dose $(\mathbf{m g} / \mathbf{k g})$ & $\begin{array}{c}\text { Mean increase in paw } \\
\text { volume }\end{array}$ & Percentage inhibition \\
\hline 1. & Control & $5 \mathrm{ml} / \mathrm{kg}$ & $0.42 \pm 0.44$ & ---- \\
\hline 2. & $K V C$ & $250 \mathrm{mg} / \mathrm{kg}$ & $0.37 \pm 0.61^{*}$ & 11.90 \\
\hline 3. & $K V C$ & $500 \mathrm{mg} / \mathrm{kg}$ & $0.35 \pm 0.62^{* *}$ & 16.66 \\
\hline 4. & Acetyl salicylic acid & $100 \mathrm{mg} / \mathrm{kg}$ & $0.28 \pm 0.64^{* *}$ & 33.33 \\
\hline
\end{tabular}

Values expressed in mean $\pm S E M$, Significant $* P<0.05 ; * * P<0.01$ compared to control; 


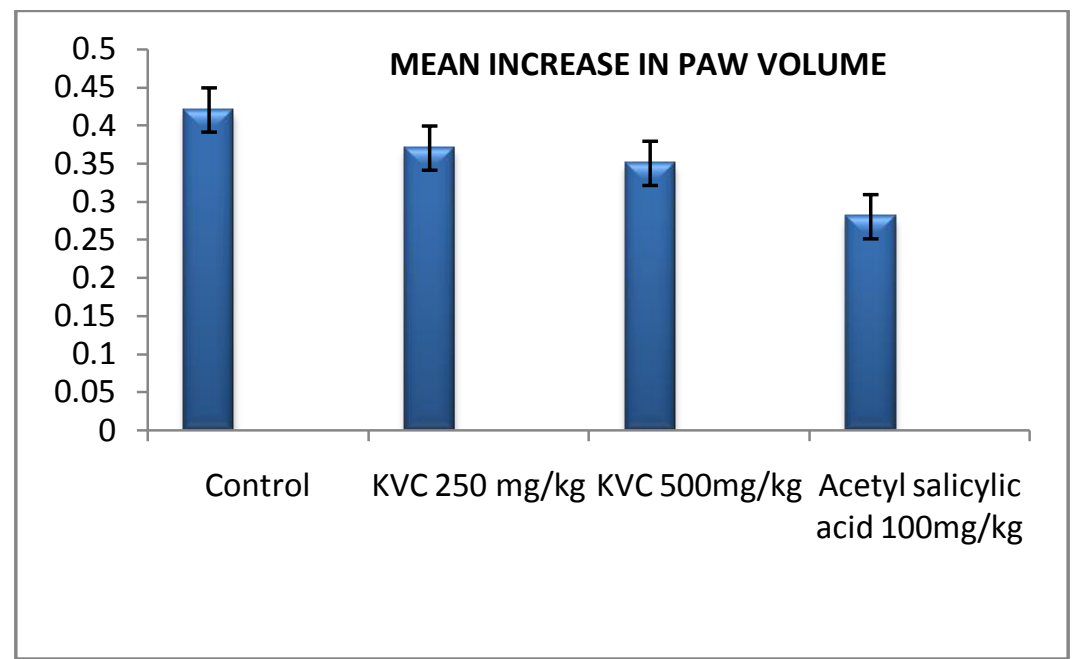

Fig-2 Effect of $K V C$ on formalin-induced edema in hind Paw of rats

Table 4. Effect of $K V C$ on Cotton pellet granuloma pouch method

\begin{tabular}{|l|l|c|c|c|}
\hline S.No & \multicolumn{1}{|c|}{ Treatment } & Dose $(\mathbf{m g} / \mathbf{k g})$ & $\begin{array}{c}\text { Granuloma weight } \\
(\mathbf{m g}) \%\end{array}$ & Percentage inhibition \\
\hline 1. & Control & $5 \mathrm{ml} / \mathrm{kg}$ & $46.42 \pm 3.44$ & ---- \\
\hline 2. & $K V C$ & $250 \mathrm{mg} / \mathrm{kg}$ & $27.37 \pm 1.65^{*}$ & 69.60 \\
\hline 3. & $K V C$ & $500 \mathrm{mg} / \mathrm{kg}$ & $26.35 \pm 2.62^{* *}$ & 76.17 \\
\hline 4. & Indomethacin & $100 \mathrm{mg} / \mathrm{kg}$ & $24.28 \pm 1.34^{* *}$ & 91.19 \\
\hline
\end{tabular}

Values expressed in mean $\pm S E M$, Significant $* P<0.05 ; * * P<0.01$ compared to control;

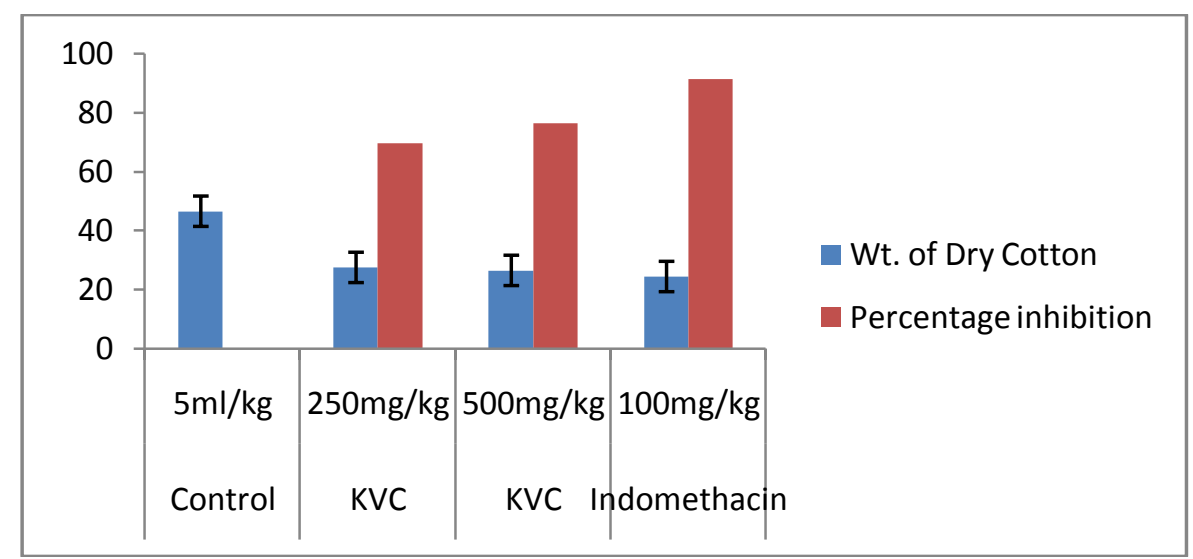

Fig-3 Effect of $K V C$ on Cotton pellet granuloma pouch method

\section{Discussion}

The result of the analgesic activity evaluated using hot plate method revealed that the reaction time for mice was significantly increased in a dose dependent manner after one hour of oral administration. It was found that both $K V C$ and Aspirin caused an inhibition on the writhing response induced by acetic acid. Doses of 250 and $500 \mathrm{mg} / \mathrm{kg}$ of the $K V C$ respectively, could completely block the writhing response exhibited about 61.51 and $72.51 \%$ inhibition. Acetic acid, which is used as an inducer for writhing syndrome, causes algesia by liberation of endogenous substances, which then excite the pain nerve endings ${ }^{[15]}$. The $K V C$ was found to exert a significant inhibitory activity on writhing response in dose range of $500 \mathrm{mg} / \mathrm{kg}$.

The results obtained rather suggest that $K V C$ posses an antinociceptive activity and the mode of action might involve a peripheral mechanism. However, the central mechanism also might be involved. Formalin induced hind paw oedema is the standard experimental model of acute inflammation ${ }^{[16]}$. In acute inflammation model, the formalin induced paw oedema was significantly reduced by all the doses of $K V C$ used when compared to control $(\mathrm{P}<0.05)$. Pain and inflammation are essential prelude to repair process ${ }^{[17]}$. The mechanism of anti inflammatory action of $K V C$ may be related with the inhibition of prostaglandin biosynthesis enzymes 
such as lipooxygenase and cyclooxygenase, increased vascular permeability and inhibition of degranulation of mast cells.

The cotton pellet-induced granuloma is widely used to assess the transudative and proliferative components of chronic inflammation ${ }^{[18]}$. It has three distinct phases: a first phase which involves transudative phase where the wet weight of the pellet increased during the first 3 hours, Second phase called an exudative phase in which plasma leaking from the blood stream around the granuloma that occurs between 3 hours and 72 hours after the cotton pellet implantation and a final third phase is proliferative phase in which the dry weight of the granuloma increased during the 3 to 6 days after the implantation ${ }^{[19]}$. The result of present study revealed that the trial drug $K V C 250$ and $K V C 500$ decrease the granuloma weight significantly in a dose dependent manner. Presence of various chemical constituents in $K V C$ justifies this anti inflammatory activity.

Hence, the drug used for the trial $K V C$ proved to be a better alternative for the commercially available allopathic drugs.

\section{Conclusion}

In conclusion, results showed Karuvilanchi Ver Chooranam has significant analgesic, anti nociceptive and anti inflammatory properties. The $K V C$ showed dose dependant anti inflammatory activity in formalin induced edema and cotton pellet granuloma pouch method. This study results confirmed the validity of traditional indications of Karuvilanchi Ver Chooranam in inflammatory disease conditions.

\section{Acknowledgement}

We wish to offer our respectable thanks to the Principal and HOD, Government Siddha Medical College, Arumbakkam, Chennai and the Vice Chancellor, Vels University, Chennai for their help, encouragement and providing the facilities to carry out this work.

\section{References}

[1]. Ikram M, Economic potential of medicinal plants. Hamdard Medicus, 26:1983; 16-17.

[2]. Hostettmann K, Bull Soc Fib Sc Nat, 76:1987; 51-63.

[3]. Mohanraj, Vadha Noi Nidhanam 800. Edn 1,( A.T.S.V.S. Siddha medical college, Kanyakumari, Tamilnadu, 2008), 163.

[4]. The wealth of India: A Dictionary of Indian Raw materials and Industrial products - Raw materials series, (Publication and information Directorate, CSIR, New Delhi, Reprints, 1999), 368.

[5]. Kannusamy Pillai C. Chikitcha Rathna Deepam. Edn 3, Vol 1, (Thirumagal Press, Chennai, 1991), 30-31.

[6]. OECD Guidelines For The Testing Of Chemicals For Acute Oral Toxicity 425- Up-And-Down-Procedure Adopted On 3 October 2008.

[7]. Lipnick R.L., Cotruvo J.A., Hill R.N., Bruce R.D., Stitzel K.A., Walker A.P., Chu I., Goddard M., Segal L., Springer J.A., and Myers R.C. Comparison of the Up-and-Down, Conventional $\mathrm{LD}_{50}$ and Fixed Dose Acute Toxicity Procedures, Fd. Chem. Toxicol., $33,1995,223-231$

[8]. Eddy, N.B., Leimback, D, Synthetic analgesics II Dithienylbutenyl and Dithenbutylamines, JPET, 107, 1953, $385-393$.

[9]. Turner RA, Screening Methods in Pharmacology, 2nd Ed. (New York, Academic Press, $1965,158$.

[10]. Collier, H.D.J., Dinnin, L.C., Johnson, C.A. and Schneider, CBr. J. Pharmacol. 32(2), 1968295.

[11]. Palanichamy S, Nagarajan S., Analgesic activity of cassia alata leaf extract and kaempferol-3-0-sophoroside. J Ethanopharmacol 29:1990; 73-8.

[12]. R. Koster, M. Anderson, and E. J. Debeer, “Acetic acid analgesic screening,” Federation Proceedings, vol. 18, pp. 412-420, 1959.

[13]. Chattopadhyay RN, Chattopadhyay R, Roy S, Moitra SK. A simple method for plethysmometric measurement of paw volume of small laboratory animals in evaluation of anti-inflammatory effects. Bull Calcutta School Trop Med 34:1986; 5-8.

[14]. Mahibalan S, Gopal N, Shanmuga Pandian P and Jasmine S, Anti-inflammatory activity of various extracts of Hedyotis umbellata linn. Natural products 4: 2008; 184-186.

[15]. N. Narayanan., P. Thirugnanasambantham, S. Viswanathan, V. Vijayasekaran, E. Sukumar, J. Ethanopharmacol, 65,1999, 237241.

[16]. MS Saluja, B Sangameswaran,A Sharma N Manocha, A Husain. Analgesic and Antiinflammatory Activity of a Marketed Poly herbal Formulation (PHF). International Journal of Pharma Professional's Research 2010.

[17]. Sherrdhara CS, Vaidhya VP, Vagdevi HM, Latha KP, Muralikrishna KS, et al. Screening of Bauhinia purpurea Linn. for analgesic and anti - inflammatory activities. Indian J Pharmacol, 41, 2009; 75-9.

[18]. Winter CA, Porter CC, Effect of alterations in the side chain upon antiinflammatory and liver glycogen activities of hydrocortisone esters. J. Am. Pharm. Assoc. Sci. Educ., 46 (9): 1957,515-519.

[19]. Swingle KF, Shideman FE, Phases of the inflammatory response to subcutaneous implantation of cotton pellet and their modification by certain anti-inflammatory agent, J Pharmacol Exp Ther 183(1),1972, 226-234. 